Correspondence

Arthur F. J. Ram

ram@rulbim.leidenuniv.nl

Received 10 April 2006

Revised 26 June 2006

Accepted 5 July 2006

\section{Database mining and transcriptional analysis of genes encoding inulin-modifying enzymes of Aspergillus niger}

\author{
Xiao-Lian Yuan, ${ }^{1} \dagger$ Coenie Goosen, ${ }^{2,3} \dagger$ Harrie Kools, ${ }^{4}$ \\ Marc J. E. C. van der Maarel, ${ }^{3,5}$ Cees A. M. J. J van den Hondel, ${ }^{1}$ \\ Lubbert Dijkhuizen ${ }^{2,3}$ and Arthur F. J. Ram ${ }^{1,6}$ \\ ${ }^{1}$ Institute of Biology Leiden, Leiden University, Fungal Genetics Research Group, \\ Wassenaarseweg 64, $2333 \mathrm{AL}$ Leiden, The Netherlands \\ ${ }^{2,3}$ Department of Microbiology, Groningen Biomolecular Sciences and Biotechnology Institute \\ (GBB), University of Groningen ${ }^{2}$ and Centre for Carbohydrate Bioprocessing TNO-University \\ of Groningen ${ }^{3}$, Kerklaan 30, 9751 NN Haren, The Netherlands \\ ${ }^{4}$ Microbiology, Fungal Genomics Group, Wageningen University, Dreijenlaan 2, 6703 HA \\ Wageningen, The Netherlands \\ ${ }^{5}$ TNO Quality of Life, Business Unit Innovative Ingredients and Products, Rouaanstraat 27, \\ 9723 CC Groningen, The Netherlands \\ ${ }^{6}$ TNO Quality of Life, Business Unit Microbiology, Utrechtseweg 48, 3500 AJ Zeist, \\ The Netherlands
}

\begin{abstract}
As a soil fungus, Aspergillus niger can metabolize a wide variety of carbon sources, employing sets of enzymes able to degrade plant-derived polysaccharides. In this study the genome sequence of $A$. niger strain CBS 513.88 was surveyed, to analyse the gene/enzyme network involved in utilization of the plant storage polymer inulin, and of sucrose, the substrate for inulin synthesis in plants. In addition to three known activities, encoded by the genes suc1 (invertase activity; designated sucA), inuE (exo-inulinase activity) and inuA/inuB (endo-inulinase activity), two new putative invertase-like proteins were identified. These two putative proteins lack $\mathrm{N}$-terminal signal sequences and therefore are expected to be intracellular enzymes. One of these two genes, designated $s u c B$, is expressed at a low level, and its expression is up-regulated when $A$. niger is grown on sucrose- or inulin-containing media. Transcriptional analysis of the genes encoding the sucrose- (sucA) and inulin-hydrolysing enzymes (inuA and inuE) indicated that they are similarly regulated and all strongly induced on sucrose and inulin. Analysis of a $\Delta c r e A$ mutant strain of $A$. niger revealed that expression of the extracellular inulinolytic enzymes is under control of the catabolite repressor CreA. Expression of the inulinolytic enzymes was not induced by fructose, not even in the $\triangle c r e A$ background, indicating that fructose did not act as an inducer. Evidence is provided that sucrose, or a sucrose-derived intermediate, but not fructose, acts as an inducer for the expression of inulinolytic genes in $A$. niger.
\end{abstract}

\section{INTRODUCTION}

Inulins are linear polymers of fructose residues (fructans), which are primarily linked by $\beta-2,1$-glycosidic bonds, and usually followed by a terminal glucose moiety. Inulin is

†These authors contributed equally to this work.

GenBank/EMBL/DDBJ accession numbers: DQ233218 (sucA), D0.233219 (sucB), D0.233220 (sucC), DQ233221 (inuA), DQ233222 (inuE) and DQ233223 (inuQ).

A supplementary table and figure are available with the online version of this paper. present as storage polysaccharide in roots and tubers of plants such as Jerusalem artichoke, chicory and dahlia (Cairns, 2003). Its presence has also been implicated in protection against water deficit in dry and cold conditions (Hendry \& Wallace, 1993; Pilon-Smits et al., 1995). Inulin in plants is synthesized by the concerted action of two fructosyltransferases, with sucrose as the primary fructosyl donor (see for review Ritsema \& Smeekens, 2003). Inulin has attracted considerable research attention because it is a relatively inexpensive and abundant substrate for the production of fructose-rich syrups, as well as a source for the production of fructo-oligosaccharides (FOS). Both 
fructose syrups and FOS are regarded as 'functional foods' since they positively influence the composition of the intestinal microflora (Yun, 1996; Roberfroid \& Delzenne, 1998; Kaplan \& Hutkins, 2003).

Yeasts and filamentous fungi employ various enzymes to degrade inulin and sucrose (Pandey et al., 1999). Apart from displaying substrate hydrolysis, some of these enzymes can also perform transfructosylation reactions, producing the trisaccharide 1-kestose from sucrose (Rehm et al., 1998; Sangeetha et al., 2004; Yanai et al., 2001) and even longer fructo-oligosaccharides (Heyer \& Wendenburg, 2001). Currently, all known fungal inulin-modifying enzymes are grouped together in family 32 of glycoside hydrolases (GH32) (http://afmb.cnrs-mrs.fr/CAZY/index. html) (Coutinho \& Henrissat, 1999). Members of family GH32 share conserved amino acid motifs and possess a similar three-dimensional protein structure (Pons et al., 1998; Alberto et al., 2004; Nagem et al., 2004).

Aspergillus niger degrades inulin using both endo-inulinases (EC 3.2.1.7), encoded by the inuA and inuB genes (Ohta et al., 1998; Akimoto et al., 1999), and an exo-inulinase (EC 3.2.1.80), encoded by the inuE gene (Moriyama et al., 2003). Endo-inulinase hydrolyses inulin internally to produce mainly inulotriose and -tetraose (Akimoto et al., 1999), whereas exo-inulinase hydrolyses the terminal $\beta-2,1$ fructosidic bonds in both sucrose and inulin (Arand et al., 2002; Kulminskaya et al., 2003; Moriyama et al., 2003). Invertase ( $\beta$-fructofuranosidase, EC 3.2.1.26), encoded by the sucl gene (Boddy et al., 1993), hydrolyses the $\beta-2,1$ glycosidic bond in sucrose to produce fructose and glucose (L'Hocine et al., 2000). A specific $\beta$-fructosyltransferase activity (EC 2.4.1.9) without significant invertase activity has been purified from A. niger strain AS0023. This enzyme transfers fructose residues from the non-reducing terminal $\beta$-2,1-glycosidic bond in sucrose to another sucrose or inulin molecule to form kestose or higher fructo-oligosaccharides (L'Hocine et al., 2000). Unfortunately, the gene encoding this enzyme activity has not been identified and characterized yet.

Recent advances in the genome sequencing of $A$. niger opened possibilities to further exploit this fungus to identify additional inulin-modifying enzymes. The full genomic sequence of $A$. niger was made available to us by DSM Food Specialties (http://www.dsm.com). Based on deduced amino acid similarities, we have identified six putative proteins that belong to family GH32. Apart from the three known fungal enzymes (InuA/B, InuE and Suc1), three new putative inulin-modifying enzymes were identified. The coding sequence for one of them appears to be a pseudogene (inuQ), while the other two genes encode intracellular invertase-like proteins that were named SucB and SucC. The transcriptional regulation of these five putative inulin/sucrose-modifying proteins in relation to various carbon sources has been studied in further detail.

\section{METHODS}

Strains and culture conditions. A. niger strain N402 used in this study was derived from the wild-type strain A. niger van Tieghem (CBS 120.49, ATCC 9029) (Bos et al., 1988). The A. niger strain used for the sequencing of the genome by DSM is CBS 513.88 (a natural derivative of strain NRRL 3122). Strain AB4.1 is a pyrG derivative of N402 (van Hartingsveldt et al., 1987) and was used to construct the creA deletion strain. A. niger strains were grown in minimal medium (MM) (Bennett \& Lasure, 1991) containing $7 \mathrm{mM} \mathrm{KCl}, 11 \mathrm{mM} \mathrm{KH} \mathrm{PO}_{4}, 70 \mathrm{mM} \mathrm{NaNO}, 2 \mathrm{mM} \mathrm{MgSO}$, $76 \mathrm{nM} \mathrm{ZnSO}, 178 \mathrm{nM} \mathrm{H} \mathrm{H}_{3} \mathrm{BO}_{3}, 25 \mathrm{nM} \mathrm{MnCl} 2,18 \mathrm{nM} \mathrm{FeSO}$, $7 \cdot 1 \mathrm{nM} \mathrm{CoCl}, 6 \cdot 4 \mathrm{nM} \mathrm{CuSO}_{4}, 6 \cdot 2 \mathrm{nM} \mathrm{Na} \mathrm{NoO}_{4}$ and $174 \mathrm{nM}$ EDTA. Erlenmeyer flasks of $300 \mathrm{ml}$ were inoculated with $2 \times 10^{6}$ spores $\mathrm{ml}^{-1}$ and incubated at $30^{\circ} \mathrm{C}$ in a rotary shaker at 300 r.p.m. for $21 \mathrm{~h}$. Each flask contained $100 \mathrm{ml} \mathrm{MM} \mathrm{(pH} \mathrm{6.5)} \mathrm{supplemented}$ with $0 \cdot 1 \%(\mathrm{w} / \mathrm{v})$ Casamino acids and $2 \%(\mathrm{w} / \mathrm{v})$ carbon source. Glucose, sucrose (BDH Chemicals), xylose, fructose and maltose (Sigma-Aldrich), inulin (Sensus Frutafit, Cosun) and starch (Windmill Starch, Avebe) were used as carbon sources. For transfer experiments, N402 was pregrown in MM supplemented with $2 \%$ $(\mathrm{w} / \mathrm{v})$ xylose or $2 \%(\mathrm{v} / \mathrm{v})$ glycerol and $0 \cdot 1 \%(\mathrm{w} / \mathrm{v})$ Casamino acids for $18 \mathrm{~h}$ at $30^{\circ} \mathrm{C}$ on a rotary shaker at 300 r.p.m. Mycelium was harvested by suction over a nylon membrane and washed with MM without carbon source. Aliquots of $1.5 \mathrm{~g}$ wet weight of mycelium were transferred to $70 \mathrm{ml} \mathrm{MM}$ containing $1 \%(\mathrm{w} / \mathrm{v})$ of various carbon sources and incubated at $30^{\circ} \mathrm{C}$ with agitation. Mycelial samples were taken at different time points by harvesting over a Miracloth filter followed by freezing in liquid nitrogen. The samples were stored at $-80^{\circ} \mathrm{C}$ prior to the isolation of total RNA. Conidiospores were obtained by harvesting spores from a plate of complete medium (minimal medium with $0.5 \%$, w/v, yeast extract and $0 \cdot 1 \%, \mathrm{w} / \mathrm{v}$, Casamino acids) containing $1 \%(\mathrm{w} / \mathrm{v})$ glucose, after 4-6 days of growth at $30{ }^{\circ} \mathrm{C}$, using a $0.9 \%(\mathrm{w} / \mathrm{v}) \mathrm{NaCl}$ solution.

Transformation of A. niger AB4.1 was as described by Punt \& van den Hondel (1992), using lysing enzymes (L1412, Sigma-Aldrich) for protoplast formation. The bacterial strain used for transformation and amplification of recombinant DNA was Escherichia coli XL-1 Blue (Stratagene). Transformation of XL-1 Blue was performed by the heatshock protocol as described by Inoue et al. (1990).

Database mining of $\boldsymbol{A}$. niger genome. The A. niger CBS513.88 genome has been determined by random sequencing of selected BACs to a $7 \cdot 5$-fold coverage. The resulting genome sequence $(35.9 \mathrm{Mb})$ consists of approximately 400 contigs, which are assembled into 19 supercontigs (Dr N. van Peij, DSM, personal communication). The sequence of the A. niger genome is currently available to academic groups and non-profit organizations on request (hans.roubos@dsm.com) after signing a Material Transfer Agreement and will be generally available after publication of the $A$. niger genome sequence ( $\mathrm{H}$. Pel and others, in preparation). Accession numbers of currently described members of families GH32 and GH68 were selected from the Carbohydrate-Active Enzymes server at http://afmb.cnrs-mrs.fr/CAZY/ Coutinho \& Henrissat, 1999), and the corresponding protein sequences were extracted from the GenBank/GenPept database and Swiss-Prot database released at http://www.ncbi.nlm.nih.gov/entrez/ and http:// www.expasy.org/sprot/. Sequences were aligned with the CLUSTALW program (Thompson et al., 1994; Chenna et al., 2003) and transformed in a hidden Markov model (HMM) profile (Eddy, 1998) with the HMMbuild program from the HMMer package at http:// hmmer.wustl.edu/. Subsequently the A. niger genome was searched using the HMM profiles and the Wise2 package from http://www. ebi.ac.uk/Wise2/. Multiple sequence alignment of known fungal fructan-modifying enzymes, based on full-length predicted protein sequences (Table 1), was performed using the CLUSTALW interface in 
Table 1. Fungal family GH32 proteins used for multiple sequence alignment in Figs 1 and 2

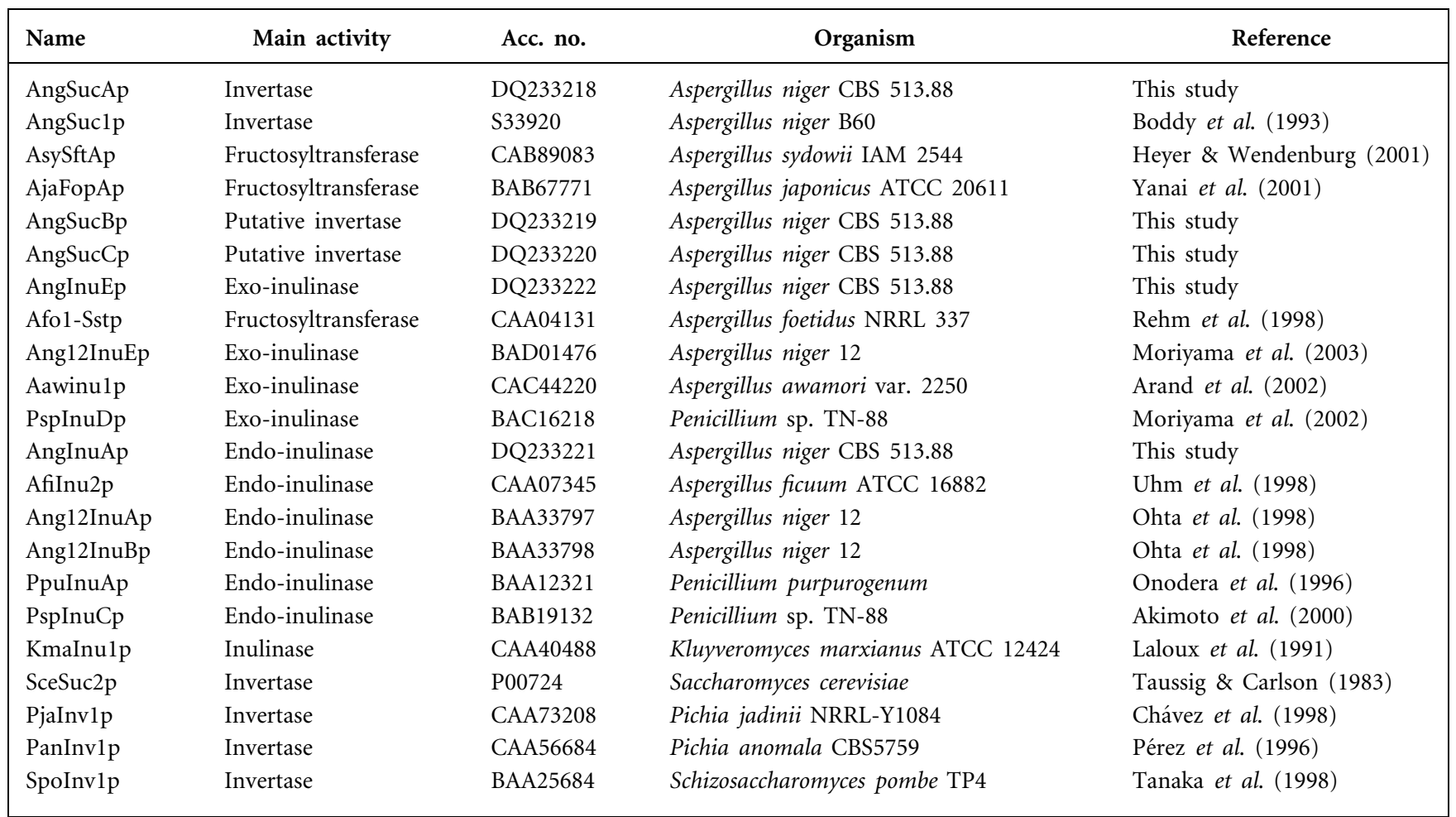

MEGA 3.1 (www.megasoftware.com) with gap-opening and extension penalties of 10 and $0 \cdot 2$, respectively. Bootstrap test of phylogeny was performed by the neighbour-joining method using 1000 replicates.

Northern analysis. Total RNA was isolated by grinding frozen $\left(-80^{\circ} \mathrm{C}\right)$ mycelium in liquid nitrogen with a pestle and mortar. Powdered mycelium (200 mg) was extracted with $1 \mathrm{ml}$ TRIzol Reagent (Invitrogen) in accordance with the supplier's instructions. For Northern analysis, $5 \mu \mathrm{g}$ total RNA was incubated with $3 \cdot 3 \mu \mathrm{l}$ $6 \mathrm{M}$ glyoxal, $10 \mu \mathrm{DMSO}$ and $2 \mu \mathrm{l} 0 \cdot 1 \mathrm{M}$ phosphate buffer $(\mathrm{pH} 7)$ in a total volume of $20 \mu \mathrm{l}$ for $1 \mathrm{~h}$ at $50^{\circ} \mathrm{C}$ to denature RNA. RNA electrophoresis was performed in a SEA-2000 electrophoresis apparatus (Elchrom Scientific) at $10^{\circ} \mathrm{C}$. The RNA samples were separated on $1.5 \%(\mathrm{w} / \mathrm{v})$ agarose gel using $0.01 \mathrm{M}$ phosphate buffer $(\mathrm{pH} 5)$ and transferred to Hybond-N filters (Amersham) by capillary blotting. Filters were prehybridized at $65^{\circ} \mathrm{C}$ for $2 \mathrm{~h}$ in a solution of $0.9 \mathrm{M} \mathrm{NaCl}, 90 \mathrm{mM}$ trisodium citrate, $1.0 \%$ (w/v) Ficoll, $1.0 \%$ $(\mathrm{w} / \mathrm{v})$ polyvinylpyrrolidone, $1.0 \%(\mathrm{w} / \mathrm{v})$ bovine serum albumin, $10 \mathrm{mM}$ EDTA, $0 \cdot 5 \%(\mathrm{w} / \mathrm{v})$ SDS and $100 \mu \mathrm{g} \mathrm{ml}^{-1}$ single-stranded herring sperm DNA. Hybridizations were performed at $42{ }^{\circ} \mathrm{C}$ for $18 \mathrm{~h}$ in a solution of $50 \%(\mathrm{v} / \mathrm{v})$ formamide, $10 \%(\mathrm{w} / \mathrm{v})$ dextran sulphate, $0.9 \mathrm{M} \mathrm{NaCl}, 90 \mathrm{mM}$ trisodium citrate, $0.2 \%$ (w/v) Ficoll, $0.4 \%(\mathrm{w} / \mathrm{v})$ polyvinylpyrrolidone, $0.4 \%(\mathrm{w} / \mathrm{v})$ bovine serum albu$\min , 0 \cdot 4 \%(\mathrm{w} / \mathrm{v})$ SDS and $100 \mu \mathrm{g} \mathrm{ml}^{-1}$ single-stranded herring sperm DNA. Blots were washed twice in high-stringency washing buffer $(30 \mathrm{mM} \mathrm{NaCl}, 3 \mathrm{mM}$ trisodium citrate and $0.5 \%$, w/v, SDS) for $20 \mathrm{~min}$ at $65{ }^{\circ} \mathrm{C}$. Probes for the detection of the six (putative) sucrose- and fructan-modifying enzymes of $A$. niger were generated using six pairs of oligonucleotide primers by PCR using $A$. niger N402 genomic DNA as template (for primer sequences see supplementary Table S1, available with the online version of this paper). The PCR-amplified fragments were run on an agarose gel and purified from the gel. The purified DNA fragments were cloned into plasmid pGEMT-easy and sequenced to confirm their identity. Probes were generated by EcoRI digestion of the pGEMT-easy vector containing the gene encoding the inulinolytic enzyme. Fragments were purified from gel and $\left[\alpha_{-}{ }^{32} \mathrm{P}\right] \mathrm{dCTP}$-labelled probes were synthesized using the Rediprime II DNA labelling system (Amersham Pharmacia Biotech) according to the instructions of the manufacturer.

Disruption of the carbon catabolite repressor CreA in $\boldsymbol{A}$. niger. The plasmid used to disrupt the creA gene was constructed as follows. The DNA fragments flanking the creA ORF were amplified by PCR using N402 genomic DNA as template: $1.4 \mathrm{~kb}$ of $5^{\prime}$ flanking DNA and $0.9 \mathrm{~kb}$ of $3^{\prime}$ flanking DNA was amplified by PCR using primers CreAP1f and CreAP2r, CreAP3f and CreAP4r (supplementary Table S1), respectively. Each primer was adapted with a restriction site for further cloning. The amplified PCR fragments were digested with NotI and BamHI or BamHI and KpnI respectively, and cloned into pBlueScriptII SK to obtain plasmids pF5 and pF3. Subsequently, pF3 was digested with BamHI and KpnI, and the fragment obtained was ligated into BamHI- and KpnI-digested pF5 to give pF53. pF53 was digested with SalI and BamHI and inserted with the SalI-BamHI fragment containing the Aspergillus oryzae pyrG gene, obtained from plasmid pAO4-13 (de Ruiter-Jacobs et al., 1989), resulting in the creA disruption plasmid pXY1.1. Plasmid pXY1.1 was linearized with NotI and transformed into AB4.1. Uridine-prototrophic transformants were selected by incubating protoplasts on agar plates containing MM without uridine. Transformants were purified and genomic DNA was isolated and analysed by PCR to identify possible $\triangle$ creA strains. Primer pairs used to identify homologous recombination of the creA deletion construct on the creA locus were CreAP5f and PAO10 or PAO9 and CreA6f. Primer pairs used in the PCR to analyse the presence of the wild-type creA gene were CreAP5f and CreAP7r, CreAP8f and CreAP6r (supplementary Table S1). Three independent creA deletion strains with identical phenotypes were obtained and designated $\mathrm{XY1.1}$ XY1.2 and XY1.3. Strain XY1.1 was further used for analysis of the expression of inulin-modifying enzymes and we will refer to 
this strain as the $\Delta c r e A$ strain in the remainder of the paper. For complementation of the $\triangle c r e A$ strain, the creA gene, including $1.3 \mathrm{~kb}$ promoter and $0.8 \mathrm{~kb}$ of terminator sequences, was amplified by PCR using primers CreAP1f and CreAP6r. The PCR product of $3.5 \mathrm{~kb}$ was cloned into pGEMT-easy (Promega) and co-transformed with pAN7.1 (Punt et al., 1987) to $\Delta$ creA strain XY1.1 to generate XY1.1-CreA.

Nucleotide accession numbers. The A. niger CBS513.88 DNA sequences encoding family GH32 members, including 1000 bp upand downstream of the ORF, and their predicted protein sequences were obtained from DSM (Dr G. Groot). The sequence data have been submitted to the GenBank database under accession numbers DQ233218 (sucA), DQ233219 (sucB), DQ233220 (sucC), DQ233221 (inuA), DQ233222 (inuE) and DQ233223 (inuQ).

\section{RESULTS}

\section{Identification of glycoside hydrolase family 32 members in the $A$. niger genome}

Glycoside hydrolase families GH32 and GH68 include invertase, levanase, inulinase and levansucrase enzymes of bacterial, fungal and plant origin (Coutinho \& Henrissat 1999; Pons et al., 1998). The two families are structurally similar (clan GH-J), sharing a similar fivefold $\beta$-propeller fold (Meng \& Futterer, 2003; Nagem et al., 2004). Protein sequences from members of families GH32 and GH68 were extracted from the GenBank/GenPept and Swiss-Prot databases and were used to construct HMM profiles to identify additional members in the genome of $A$. niger CBS513.88. Family GH68 profiles did not return any significant matches. The family GH32 profile returned five significant sequences. In addition to three family GH32 members already described for A. niger - invertase (Suc1, Boddy et al., 1993), exo-inulinase (InuE, Moriyama et al.,
2003) and endo-inulinases (InuA/InuB, Ohta et al., 1998) two new members were identified, which were named SucB and SucC.

A neighbour-joining tree based on phylogenetic analysis of all currently available functionally described family GH32 fungal protein sequences was constructed. As shown in Fig. 1, four subgroups of fungal inulinolytic enzymes can be distinguished: (i) exo-inulinases/fructosyltransferases, (ii) endo-inulinases, (iii) yeast invertases/inulinases and (iv) invertases from filamentous fungi. The complete inventory and the notion that these four groups are evident within the fungal GH32 enzymes had not been noticed in earlier studies in which phylogenetic trees of GH32 family proteins had been constructed (Pons et al., 1998; Moriyama et al., 2003). In the secondary structure of microbial GH32 proteins eight well-conserved domains (A, B, B1, C, D, E, F and G, respectively) can be distinguished (Pons et al., 1998; Ohta et al., 1998). Domains A, D and E (designated blocks I, II and III by Pons et al., 2004) contain highly conserved acidic residues that are located in the active site of members of family GH32. These highly conserved acidic domains, as well as the other conserved domains, are also present in most of the fungal fructan-modifying enzymes (Fig. 2).

It has been previously reported that A. niger strain 12 contains two genes encoding endo-inulinases that differ by only 8 of the 516 amino acids (Ohta et al., 1998). In the genome sequence of $A$. niger strain CBS513.88, a single gene encoding an endo-inulinase could be identified. The presence of single-copy endo-inulinase genes in A. niger strains CBS513.88 and N402 was confirmed by Southern blot analysis (data not shown). Sequence comparison of the endo-inulinases of strains CBS513.88 and 12 revealed that

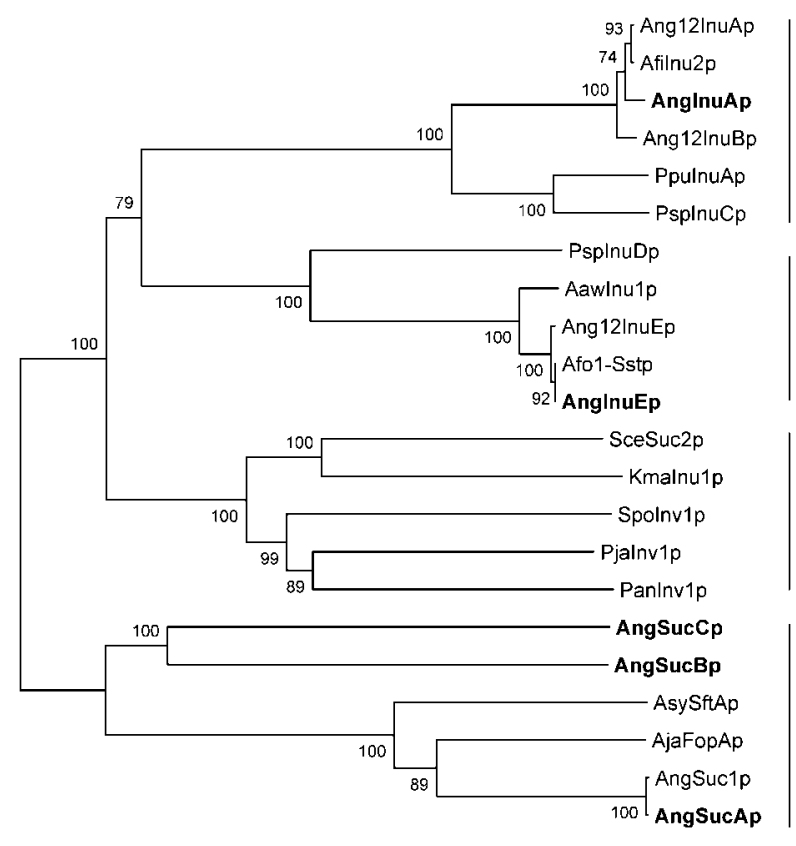

Endo-inulinase
Filamentous fungi Invertase

Exo-inulinase/

Fructosyltransferases

Yeast

Invertase/inulinase (n)

\begin{abstract}
Fig. 1. Neighbour-joining tree of functionally characterized GH32 family members from filamentous fungi and yeast species. GH32 proteins identified in the genome of $A$. niger CBS513.88 are shown in bold. The proteins, their main activities, accession numbers, and the source (organisms) of the protein sequences used in this alignment, are listed in Table 1. Bootstrap values are indicated on the node of each branch. The tree was created with MEGA 3.1 using default settings for gap and extension penalties. The bar indicates $10 \%$ amino acid sequence difference.
\end{abstract}




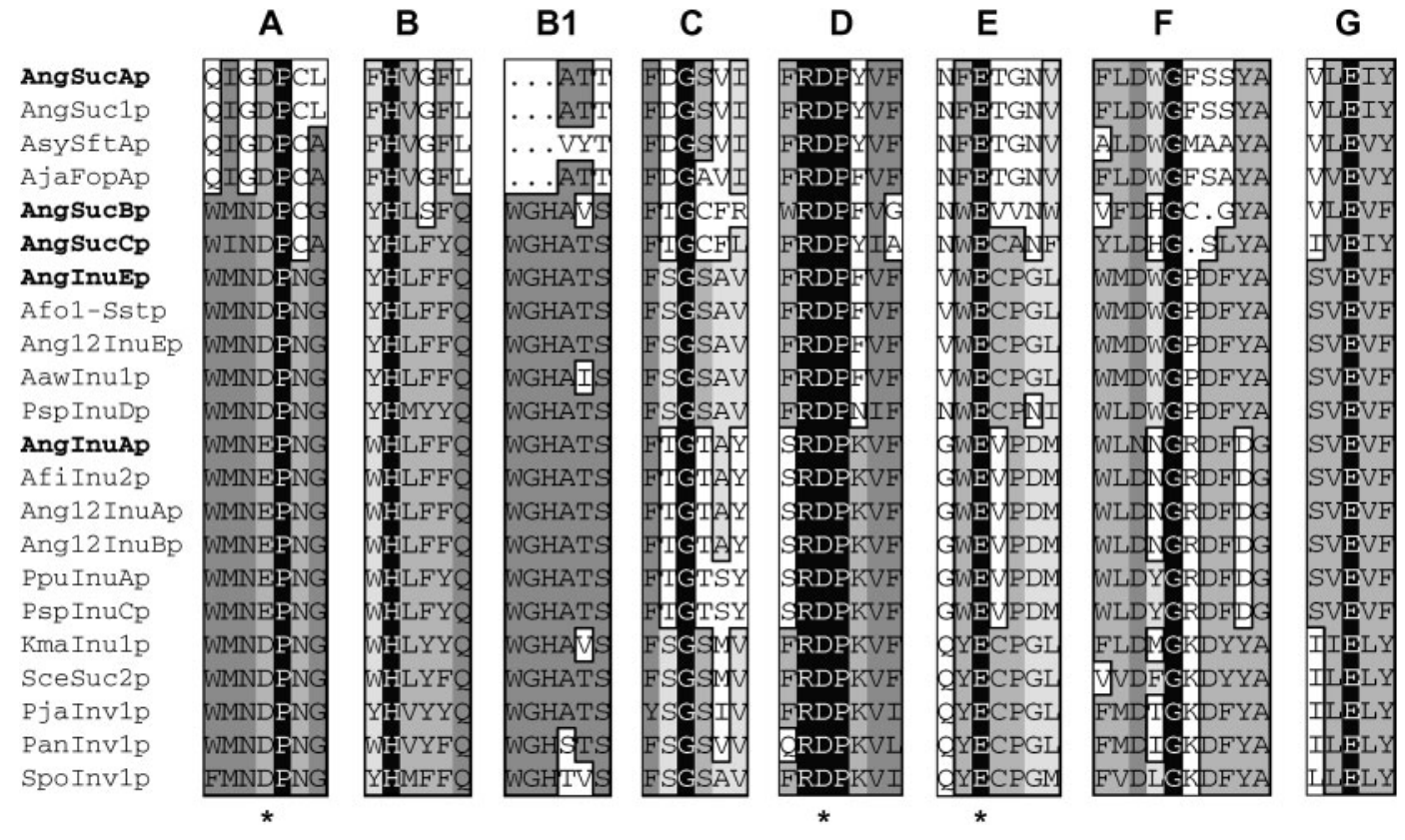

\begin{abstract}
Fig. 2. Conserved domain alignment of family GH32 enzymes from filamentous fungi and yeast species. Conserved residues are shaded by different intensities based on homology level in the alignment. Black, $100 \%$ homology; dark grey, $\geqslant 75 \%$ homology; light grey, $\geqslant 50 \%$ homology; very light grey, $\geqslant 33 \%$ homology. Conserved acidic residues are indicated with an asterisk $\left({ }^{*}\right)$. The eight conserved domains (A, B, B1, C, D, E, F and G) are indicated at the top. Proteins used are also shown in Fig. 1 and listed in Table 1.
\end{abstract}

the enzyme from strain CBS513.88 displayed higher similarity to InuA ( 9 amino acid differences) than to InuB (15 amino acid differences) of strain 12 . The single endo-inulinase in strain CBS513.88 has been designated InuA.

Besides the three known inulinolytic activities, two previously unknown GH32 family members were identified in the $A$. niger CBS513.88 genome sequence. Unlike the SucA, InuA and InuE proteins, SucB and SucC lack an Nterminal signal sequence, or any other recognizable targeting signal, which suggests that the proteins are localized intracellularly, in the cytosol. The SucB and SucC protein sequences were analysed using SecretomeP $1.0 \mathrm{~b}$ prediction (http://www.cbs.dtu.dk/services/SecretomeP1.0) (Bendtsen et al., 2004) to assess if these enzymes might be secreted via a non-classical secretion pathway. Both enzymes have an $\mathrm{NN}$-score close to the threshold value of $0.6(0.651$ for SucB and 0.586 for SucC), which does not exclude the possibility that the two proteins are secreted via a non-classical secretion pathway. This result should be interpreted with care, as the program has been trained using sequences of human non-classical exported proteins.

Phylogenetic analysis indicated that SucB and SucC group together with fungal invertases (Fig. 1). Comparison of the deduced amino acid sequence of SucB with all functionally described GH32 family proteins revealed highest identity to the $A$. niger SucA protein (24\% identity, $41 \%$ positives, evalue of $\left.4 \times 10^{-32}\right)$. SucC also displays the highest identity to the A. niger SucA protein (28\% identity, $42 \%$ positives, evalue of $\left.2 \times 10^{-43}\right)$. Pairwise comparison indicated that SucB and SucC have higher identity to each other $(35 \%$ identity, $52 \%$ positives, e-value of $2 \times 10^{-97}$ ) than to any other functionally annotated GH32 family member (Fig. 1). The $s u c B$ and $s u c C$ genes encode proteins of 617 and 601 amino acids respectively, and contain all conserved domains $(A-G)$, including the conserved acidic residues in domains A, D and E (Fig. 2).

\section{Identification of glycoside hydrolase family 32 members in other fungal genomes}

The genomes of the ascomycete fungi Aspergillus nidulans, Aspergillus fumigatus, Neurospora crassa, Gibberella zeae and Magnaporthe grisea and the basidiomycete fungus Ustilago maydis were analysed for the presence of GH32 family members. The results are summarized in Table 2 and a phylogenetic tree is available as supplementary Fig. S1. A. nidulans contains two genes that encode proteins belonging to the GH32 family. AN5012.2 displays the highest identity to the $A$. niger InuE and probably represents the extracellular A. nidulans sucrose-hydrolysing activity described by Vainstein \& Peberdy (1990, 1991). An invertase similar to the A. niger SucA protein appears to be absent in A. nidulans. The second member of the GH32 family (AN3837.2) has high identity to the $A$. niger SucB protein (Table 2). As in $A$. niger, the protein is predicted to be intracellular in $A$. nidulans, as an N-terminal signal sequence is not present. Orthologues of an endo-inulinase (InuA-like) or a second 
Table 2. Inventory of $\mathrm{GH} 32$ proteins in genomes of filamentous fungi

\begin{tabular}{|c|c|c|c|c|}
\hline Fungus & ORF no. & Accession no. & Closest $A$. niger homologue & Predicted localization $\dagger$ \\
\hline \multirow[t]{2}{*}{ A. nidulans } & AN3837.2 & EAA59102 & SucB; $1 \mathrm{e}-144$ & Intracellular \\
\hline & AN5012.2‡ & EAA61090 & InuE; $4 \mathrm{e}-166$ & Extracellular \\
\hline \multirow[t]{4}{*}{ A. fumigatus } & Afu2g01240 & EAL87222 & InuE; $2 \mathrm{e}-70$ & Extracellular \\
\hline & Afu5g00530 & EAL86248 & InuA; $4 \mathrm{e}-183$ & Extracellular \\
\hline & Afu5g00480 & EAL86253 & InuE; $3 \mathrm{e}-169$ & Extracellular \\
\hline & Afu6g05000 & EAL85540 & SucB; $1 \mathrm{e}-182$ & Intracellular \\
\hline N. crassa & NCU04265.2 & CAC28747 & InuE; $3 \mathrm{e}-41$ & Extracellular \\
\hline \multirow[t]{5}{*}{ G. zeae } & FG02067.1 & EAA69589 & InuA; $5 \mathrm{e}-05$ & Intracellular \\
\hline & FG02339.1 & EAA69879 & InuE; 7e-59 & Extracellular \\
\hline & FG03288.1 & EAA72735 & SucC; e-136 & Intracellular \\
\hline & FG06451.1 & EAA78236 & InuE; $4 \mathrm{e}-61$ & Extracellular \\
\hline & FG08415.1‡ & EAA71892 & SucA; $0 \cdot 0$ & Extracellular \\
\hline \multirow[t]{5}{*}{ M. grisea } & MG02507.4 & XP_365805 & InuE; $1 \mathrm{e}-55$ & Extracellular \\
\hline & MG05785.4 & XP_369679 & SucA; 2e-49 & Extracellular \\
\hline & MG07837.4 & XP_367933 & SucB; $8 \mathrm{e}-36$ & Extracellular \\
\hline & MG10748.4 & XP_360436 & SucA; $1 \mathrm{e}-08$ & $\begin{array}{l}\text { Truncated protein; domains } \\
\text { A, B1, B, C, D, F are missing }\end{array}$ \\
\hline & MG10767.4‡ & XP_360455 & SucA; $2 \mathrm{e}-14$ & Extracellular \\
\hline \multirow[t]{2}{*}{ U. maydis } & UM01945.1 & EAK82399 & InuE; $1 \mathrm{e}-66$ & Extracellular \\
\hline & UM03605.1 & EAK84508 & SucB; $2 \mathrm{e}-89$ & Intracellular \\
\hline
\end{tabular}

${ }^{*}$ BLASTP searches were performed with the full-length protein sequences.

$\dagger$ Localization was predicted using the SignalP 3.0 Prediction program at http://www.cbs.dtu.dk/services/SignalP/. Proteins with a predicted Nterminal signal sequence were considered as extracellular proteins. Proteins lacking an $\mathrm{N}$-terminal signal sequence were considered as intracellular enzymes.

¥Annotation improved manually.

intracellular invertase-like protein (SucC-like), as found in A. niger, were not found in the A. nidulans genome. A. fumigatus contains four genes that encode proteins belonging to the GH32 family. Based on the sequence alignments, Afu5g00530 and Afu5g00480 are likely to encode the endoand exo-inulinases, respectively. Afu6g05000 is highly similar to the $A$. niger SucB protein and also predicted to be intracellularly localized. The fourth GH32 family member, Afu2g01240, shows the highest sequence identity to yeast-like invertases, also reflected in the neighbourjoining tree (Fig. S1). N. crassa contains only a single GH32 family member. This protein displays the highest sequence identity with $\beta$-fructofuranosidases of bacterial origin (Bacillus megaterium FruA; e-value $3 \times 10^{-72}$ ) (Chiou et al., 2002) and groups in the fungal tree together with the yeast-like invertases (Fig. S1). G. zeae (anamorph Fusarium graminearum) contains five GH32 family members. FG08415.1 is the putative orthologue of the A. niger SucA protein. In the original annotation, the protein lacks an $\mathrm{N}$-terminal signal sequence. However, deleting the first 81 amino acids of the predicted protein sequence renders a protein of 619 amino acids, containing a predicted signal sequence. FG02339.1 is most homologous to the Saccharomyces cerevisiae Suc2 protein (e-value $3 \times 10^{-82}$ ) and clusters together with yeast-like invertases. FG03288.1 encodes a protein with high identity to the SucC protein of
A. niger. The protein is also predicted to be intracellularly localized. FG06451.1 shows the highest identity (e-value $1 \times 10^{-72}$ ) to the Bacillus subtilus SacC protein, which has levanase activity (Martin et al., 1987). FG02067.1 is an interesting member of the GH32 gene family as it shows very limited sequence identity to the known enzymes. It is predicted to be an intracellular enzyme and shows the highest identity (e-value $2 \times 10^{-09}$ ) to a cycloinulooligosaccharide fructanotransferase from Bacillus macerans (Kim \& Choi, 2001). M. grisea contains five GH32 enzymes, four of which cluster in a separate branch different from the other fungal proteins (Fig. S1). One of the predicted enzymes (MG10748.4) is N-terminally truncated because the ORF is at the end of a contig. The annotation of MG10767.4 has been improved, resulting in a protein that contains all the conserved GH32 domains. MG02507.4 clusters in the group of yeast-like invertases (Table 2, Fig. S1), whereas the remaining four form a distinct group with high sequence identities to each other (e-value $1 \times 10^{-112}$ or lower). Three of the enzymes are predicted to be secreted; for the fourth protein this is not known ( $\mathrm{N}$-terminally truncated because this ORF is at the end of a contig). It will be of interest to characterize the biochemical properties of those enzymes. Finally, $U$. maydis contains two GH32 family members. UM01945.1 encodes a protein that is most similar to yeastlike invertases, while UM03605.1 encodes a predicted 
intracellular protein most closely related to the A. niger SucC protein.

The comparison of the GH32 enzymes from various filamentous fungi thus reveals that different fungi contain different repertoires for the utilization of inulin and/or sucrose. Intracellularly located GH32 enzymes appear not to be unique to A. niger, as the presence of these proteins is also predicted in the other fungi (Table 2). With one exception (FG02067), these enzymes cluster as a distinct group in the phylogenetic tree (Fig. S1).

\section{Transcriptional regulation of inulin-modifying enzymes in $\boldsymbol{A}$. niger}

The expression of the five putative inulin/sucrose-modifying enzymes identified in the genome of $A$. niger in relation to the presence of different carbon sources was studied by Northern blot analysis. RNA was extracted from A. niger N402 mycelia grown in minimal medium containing xylose, glucose, maltose, starch, fructose, sucrose or inulin (all $2 \%$, $\mathrm{w} / \mathrm{v})$ as sole carbon source. Expression of the inuE, sucA and inuA genes could be detected only on sucrose and inulin (Fig. 3a). sucB was not only expressed in the presence of sucrose and inulin; weak expression was also detected on other carbon sources (Fig. 3a). SucB expression on glucose and maltose was detected after longer exposure of the Northern blot (not shown). The detection of two differentsized mRNAs for the sucB gene suggests two different mRNA start sites, or two different polyadenylation sites. The presence or absence of one of the two mRNAs was not

(a)

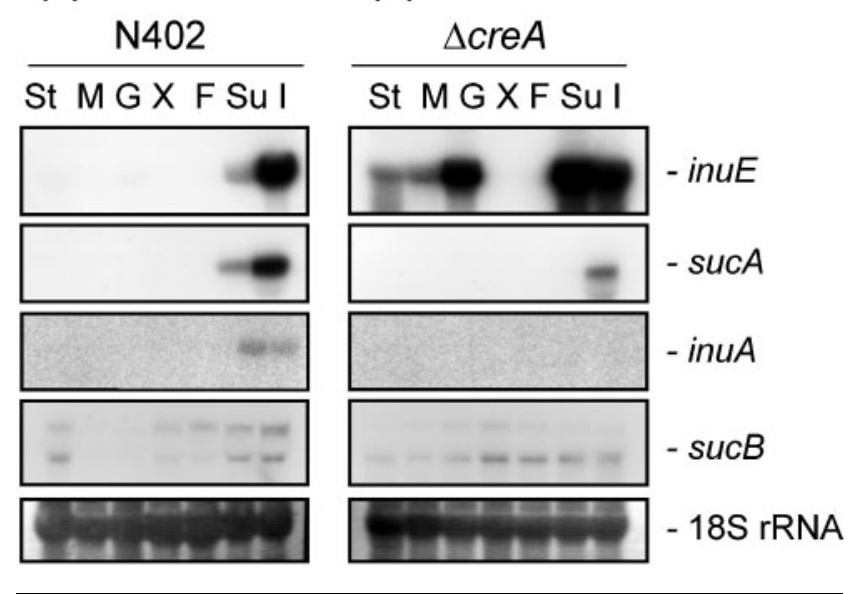

Fig. 3. Expression analysis of $A$. niger inulinolytic genes in wild-type $\mathrm{N} 402$ (a) and the $\Delta c r e A$ strain (b). Total RNA was extracted from mycelia grown for $21 \mathrm{~h}$ at $30^{\circ} \mathrm{C}$ in MM containing $2 \%(\mathrm{w} / \mathrm{v})$ of different carbon sources. RNA $(10 \mu \mathrm{g})$ was separated by agarose gel electrophoresis, blotted, and hybridized with ${ }^{32} \mathrm{P}$-labelled probes specific for inulinolytic genes. St, starch; M, maltose; G, glucose; X, xylose; F, fructose; Su, sucrose; I, inulin. Ethidium bromide staining of $18 \mathrm{~S}$ rRNA was used as loading control. correlated with a particular carbon source. Expression of sucC was not detected on any of the carbon sources tested (results not shown). The differences in expression level of the various genes (relatively low on sucrose and high on inulin) might be caused by differences in the growth stage of the cultures. Growth of $A$. niger on sucrose is much faster than that on inulin. After $21 \mathrm{~h}$, the sucrose-grown culture was in the mid-exponential phase of growth, while the inulin-grown culture was still in the early exponential phase (data not shown).

The expression of genes encoding inulinolytic enzymes was also studied using transfer experiments. A. niger strain $\mathrm{N} 402$ was pre-grown in $2 \%(\mathrm{w} / \mathrm{v})$ xylose medium for $18 \mathrm{~h}$ and mycelium was transferred to either $1 \%(\mathrm{w} / \mathrm{v})$ inulin, $1 \%$ $(\mathrm{w} / \mathrm{v})$ sucrose or $1 \%(\mathrm{w} / \mathrm{v})$ maltose medium and grown further for 2, 4, 8 and $24 \mathrm{~h}$. Since the inulinolytic genes were not expressed on xylose (Fig. 3a), this carbon source was chosen for pre-culturing. Mycelia were isolated before the transfer $(t=0 \mathrm{~h})$ and at specific time points after the transfer $(2,4,8$ and $24 \mathrm{~h})$ and total RNA was isolated and subjected to Northern analysis. As expected, no expression of inulinolytic enzymes was observed during growth on xylose (Fig. $4, t=0 \mathrm{~h}$ ). The expression of all four genes, inuE, sucA, inuA and $s u c B$, was induced after transfer from xylose to sucrose and inulin (Fig. 4). No induction of any of the inulinolytic genes was observed on maltose, although a low level of expression of inuE could be observed. The induction of genes on sucrose was much faster and more dramatic compared to the response to inulin, reflecting the much faster growth on sucrose than on inulin (see above). The expression of the inuE, sucA and inuA genes decreased

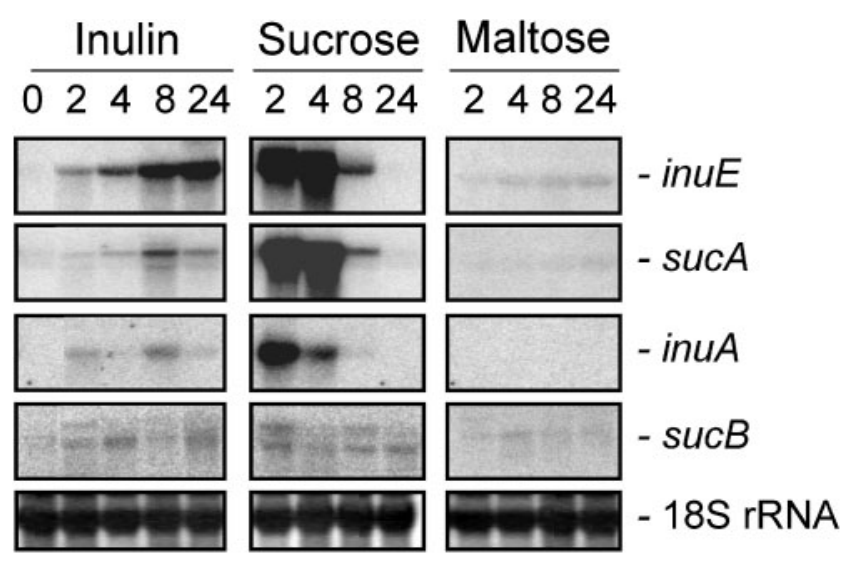

Fig. 4. Northern blot analysis of inulinolytic genes in $A$. niger wild-type strain after transfer from xylose to different carbon sources. A. niger was pregrown in $\mathrm{MM}$ containing $2 \%(\mathrm{w} / \mathrm{v})$ xylose and $0.1 \%(\mathrm{w} / \mathrm{v})$ Casamino acids at $30^{\circ} \mathrm{C}$ for $18 \mathrm{~h}$. Total RNA was prepared from mycelia grown for 2, 4, 8 and $24 \mathrm{~h}$ after transfer from pregrown culture to fresh MM containing $1 \%(\mathrm{w} / \mathrm{v})$ inulin, $1 \%(\mathrm{w} / \mathrm{v})$ sucrose or $1 \%(\mathrm{w} / \mathrm{v})$ maltose; $5 \mu \mathrm{g}$ total RNA was loaded on the gel. Ethidium bromide staining of $18 \mathrm{~S}$ rRNA was used as loading control. 
after $4 \mathrm{~h}$ growth on sucrose, probably due to the rapid utilization or conversion of the available sucrose. As inulin was utilized more slowly, expression levels remained higher for a longer period. The results in Fig. 4 also indicate that, although the different genes are co-regulated and all induced on sucrose or inulin, there were slight differences in expression pattern. Whereas the inuE transcript remains present most abundantly at $24 \mathrm{~h}$ after transfer to inulin, the levels of sucA and inuA mRNA had already decreased. We have no conclusive explanation for these observations; these differences may be due to differences in mRNA stability, or to expression also being under control of multiple regulatory mechanisms such as $\mathrm{pH}$ regulation, mediated by the PacC transcriptional regulator, or carbon catabolite repression, mediated by the CreA repressor protein. The presence of binding sites for PacC ( $5^{\prime}$-GCCARG-3') (see for review Penalva \& Arst, 2002) and CreA (5'-SYGGRG-3') (see for review Ruijter \& Visser, 1997) in the promoters of most of these genes might support the latter explanation.

\section{Expression analysis of the inulinolytic genes in a $\triangle c r e A$ background}

In the yeast Kluyveromyces fragilis, fructose has been described as an inducer of inulinase expression (Grootwassink \& Hewitt, 1983). The results shown in Fig. 3(a) indicate that the genes encoding the inulinolytic enzymes are not expressed on fructose in A. niger. This might be caused by the high concentration of fructose used, resulting in carbon catabolite repression mediated by CreA. Therefore, the expression of genes encoding inulinolytic enzymes was also examined in a $\triangle c r e A$ mutant of $A$. niger strain N402. A $\triangle$ creA null mutant was generated and verified as described in Methods. The phenotype of the $\Delta$ creA strain was similar to that described for severe creA mutants in other A. niger strains and in A. nidulans (Ruijter \& Visser, 1997; Shroff et al., 1997), including reduced radial growth and reduced conidiation (data not shown). Transformation of the $\Delta$ creA strain with the wild-type creA gene fully complemented the reduced growth and reduced conidiation phenotype of the $\Delta c r e A$ strain (data not shown).

The expression analysis of the inuE gene in the $\Delta c r e A$ strain showed that the expression of this gene was higher than in the wild-type strain, indicating that it is under control of carbon metabolite repression. Expression of $i n u E$ was found in the $\Delta$ creA strain after growth on glucose, and to some extent on maltose and starch. This is in contrast to the expression of inuE on xylose and fructose, which was undetectable in both the wild-type and the $\Delta c r e A$ strain. Apparently, the expression of the $i n u E$ gene requires an activator or inducer molecule and is not expressed under derepressing $(\triangle c r e A)$ conditions. Inspection of the $1 \mathrm{~kb}$ promoter sequence of the inuE gene revealed the presence of 13 putative CreA-binding sites that might be involved in mediating repression, but their functionality has not been studied. Analysis of the expression of the other genes encoding inulinolytic enzymes showed a different expression pattern in the $\triangle$ creA strain. sucA and inuA, both expressed specifically on inulin and sucrose in the wild-type strain, were expressed at a lower level $(s u c A)$, or not detectable (inuA) in the $\triangle$ creA strain (Fig. $3 \mathrm{~b}$ ). Expression of sucA and inuA was not detected after growth on xylose and fructose, similar to what was observed for $i n u E$. In contrast to the expression profile of the inuE gene, no expression was detected of sucA and inuA after growth on starch, maltose and glucose. Thus, although CreA-binding sites are present in the $1 \mathrm{~kb}$ promoter regions of the sucA and the inuA genes (six and five sites, respectively), the expression of both genes does not seem to be directly controlled by CreA. Disruption of catabolite repression in the $\Delta c r e A$ strain could lead to the inactivation of complex pathways, which might bring about decreased or total loss of expression. The expression pattern of $s u c B$ also suggests that this gene is, like inuE, under carbon catabolite repression control. sucB is not exclusively expressed on inulin and sucrose, but also on starch, xylose and fructose, and to a lesser extent on maltose and glucose (Figs 3 and 4). Expression of the $s u c B$ gene in the $\Delta c r e A$ background showed two remarkable features: (i) expression of $s u c B$ in the $\triangle c r e A$ strain was also detected on maltose and glucose, in addition to the other carbon sources, indicating that CreA mediated catabolite repression of $s u c B$ on maltose and glucose in the wild-type strain; (ii) expression of $s u c B$ in the $\Delta$ creA background favours the transcription of the smaller-sized mRNA molecule. The $1 \mathrm{~kb}$ promoter region of sucB contains seven putative CreA-binding sites. Expression of the sucC gene was also not detected in the $\Delta c r e A$ mutant (data not shown). Clearly, the different responses of inuE, sucB and sucA/inuA in a $\triangle$ creA mutant background suggest the involvement of additional factors other than the presence of an inducer and repression via CreA. These might include environmental factors such as $\mathrm{pH}$, nitrogen availability and temperature.

\section{Sucrose acts as an inducer of the inulinolytic system in $A$. niger}

Fructose has been shown to induce expression of inulinase in the yeast K. fragilis (Grootwassink \& Hewitt, 1983). The expression analysis of the inulinolytic genes in the wild-type A. niger strain and the $\Delta c r e A$ strain after growth on fructose did not result in detectable expression of any of the genes, indicating that fructose is not the inducing molecule for expression (Fig. 3).

Further evidence that fructose did not act as an inducer for the expression of the inulinolytic genes was obtained in a transfer experiment. Wild-type A. niger strain N402 was pregrown in $2 \%(\mathrm{w} / \mathrm{v})$ glycerol minimal medium for $18 \mathrm{~h}$ and mycelium was transferred to minimal medium containing decreasing concentrations of fructose: $50 \mathrm{mM}, 5 \mathrm{mM}$, $500 \mu \mathrm{M}, 50 \mu \mathrm{M}, 5 \mu \mathrm{M}, 500 \mathrm{nM}, 50 \mathrm{nM}, 5 \mathrm{nM}$, and no carbon sources. As shown in Fig. 5(a), this gradual decrease in fructose did not result in expression of the different inulinolytic genes, not even after $4 \mathrm{~h}$ of growth. A similar transfer experiment was performed to medium containing sucrose in an identical concentration series. As expected, sucrose induced expression of the genes encoding the 
(a)

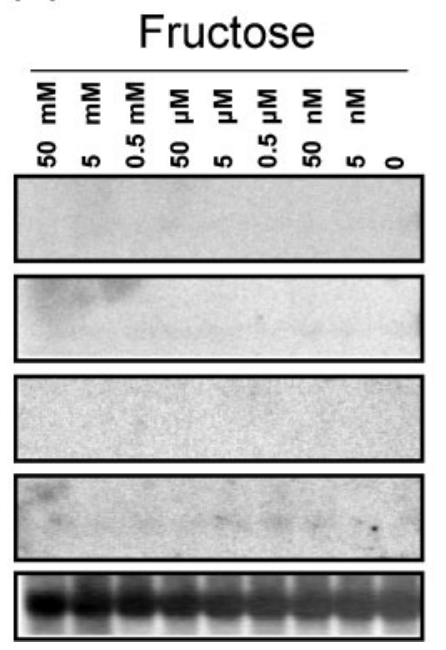

(b)

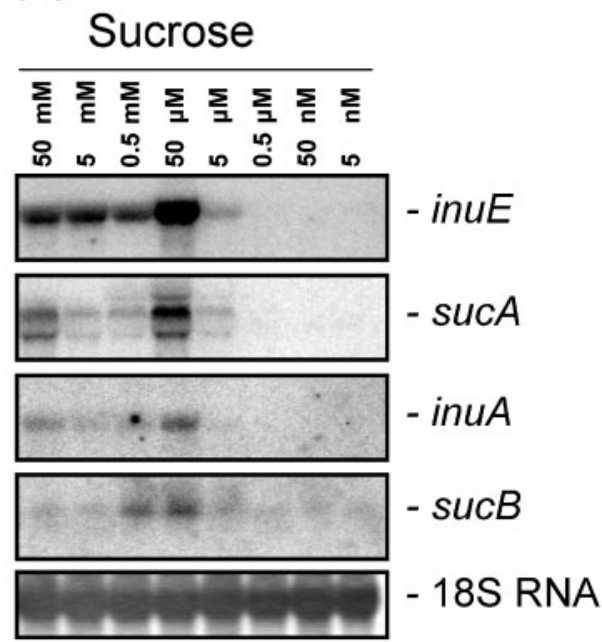

Fig. 5. Northern blot analysis of genes encoding inulinolytic enzymes of $A$. niger $\mathrm{N} 402$ using carbon-shift experiments. $A$. niger was pregrown in $\mathrm{MM}$ containing $2 \%$ (w/v) glycerol at $30^{\circ} \mathrm{C}$ for $18 \mathrm{~h}$. Total RNA was prepared from mycelia grown for $4 \mathrm{~h}$ after transfer to fresh MM containing concentrations of fructose (a) or sucrose (b) as indicated; $5 \mu \mathrm{g}$ total RNA was loaded on the gel. Ethidium bromide staining of $18 \mathrm{~S}$ rRNA was used as loading control. inulinolytic enzymes (Fig. 5b). The induction of inuE, sucA, inuA and $s u c B$ reached the highest level at $50 \mu \mathrm{M}$ sucrose, indicating that some form of repression at high sucrose concentrations may exist, e.g. catabolite repression by released glucose from sucrose hydrolysis. The addition of $50 \mu \mathrm{M}$ or $5 \mu \mathrm{M}$ of glucose, 1-kestose or 1-nystose did not trigger induction of the inulinolytic system (data not shown).

\section{DISCUSSION}

The availability of the $A$. niger genome sequence and subsequent search for inulinolytic enzymes using HMM profiles generated for GH32 family members has allowed identification of five putative enzymes acting on inulin and/or sucrose in the genome of $A$. niger. A sixth gene was identified, but considered as a pseudogene because of the various stop codons that were present in the predicted ORF. In addition to three extracellular inulinolytic activities of $A$. niger, the invertase encoded by the sucl gene, the exoinulinase encoded by the inuE gene, and the endo-inulinase activity encoded by the inuA gene, two additional genes, $s u c B$ and $s u c C$, were identified. We will briefly discuss the different enzymes in the genome of $A$. niger strain CBS513.88 in relation to previously identified enzymic activities in Aspergillus spp. and in relation to their activity. The $A$. niger invertase activity has been shown to be encoded by the sucl gene (Boddy et al., 1993). The Suc1 protein from A. niger strain B60 has been described as a 566 amino acid protein; its protein sequence is identical to that of the SucA protein encoded by the genome of $A$. niger CBS513.88. The Sucl protein groups in the phylogenetic tree with the previously described fructosyltransferase FopA (Yanai et al., 2001). FopA was originally published as an enzyme from A. niger strain ATCC 20611, but this strain has been reclassified as an Aspergillus japonicus strain (ATCC culture collection database; http://www.lgcpromochem-atcc.com/). Compared to the Sucl protein sequence (Boddy et al., 1993),
FopA has an extra C-terminal extension consisting of 38 amino acids (Yanai et al., 2001). We have re-examined the sucl coding region and from that analysis we predict the existence of a 55 bp intron sequence 1 bp upstream of the termination codon. Taking the intron sequence into account, the Sucl protein is predicted to become 39 amino acids longer than the sequence published by Boddy et al. (1993). To verify our prediction, the sucl cDNA was amplified using RT-PCR and sequenced, which confirmed the presence of the intron (data not shown). We have renamed the $s u c 1$ gene as $s u c A$, to meet the general nomenclature rules for A. niger. Although the A. niger SucA protein is $67 \%$ identical to the FopA protein, and both proteins cluster in the same branch of the phylogenetic tree, the enzymic activities of the two proteins appear to be different. FopA displays a much higher fructosyltransferase activity than Suc1 from A. niger strain B60 (Yanai et al., 2001). SucA, which is identical to Suc1, is therefore likely to encode a fructofuranosidase lacking any detectable fructosyltransferase activity under the given assay conditions. A second fungal fructosyltransferase-encoding gene was identified in Aspergillus sydowi (sftA) (Heyer \& Wendenburg, 2001), which clusters with FopA and SucA (Fig. 1). The sftA gene was only expressed in the conidia of A. sydowi, and its product $\mathrm{SftA}$ is capable of producing fructo-oligosaccharides up to 40 fructose units long (in vitro). High-molecular-mass polymers were detected when intact conidia were incubated with sucrose as substrate. Unexpectedly, these two transferases (SftA and FopA) did not show a higher sequence identity to each other than to SucA. Our sequence alignment did not reveal any obvious differences between the proteins that could explain their different reaction specificities. SucA orthologues were not identified in the genomes of $A$. nidulans and $A$. fumigatus.

A surprising finding was the presence of only one copy of an endo-inulinase gene in the $A$. niger genomes of strain CBS513.88 and N402. Previous studies with A. niger strain 
12 revealed the presence of two very similar genes, inuA and inuB, both encoding endo-inulinase (Ohta et al., 1998). Expression analysis revealed that only the inuB gene is transcribed actively (Akimoto et al., 1999). Most likely, the presence of the two genes is a result of a recent duplication event that is specific for $A$. niger strain 12 and has not occurred in A. niger strains CBS513.88 and N402.

The inuE gene encodes a third known inulinolytic enzyme, an exo-inulinase, characterized from A. niger strain 12 (Moriyama et al., 2003). The putative exo-inulinase from CBS513.88 is $99 \%$ identical to InuE from A. niger 12 and $100 \%$ identical to Aspergillus foetidus fructosyltransferase 1Sst (Rehm et al., 1998); the latter was shown to produce 1kestose in the presence of high concentrations of sucrose. However, Moriyama et al. (2003) did not detect transfructosylation activity in the culture filtrate of a Pichia pastoris strain expressing inuE, although the enzyme was incubated at substrate concentrations where transfructosylation should occur $(150 \mathrm{mM})$, as reported by Rehm et al. (1998). It appears unlikely that the three amino acid differences between 1-Sst and InuE affect reaction specificity since the differences involve similar amino acid residues: His199Gln, Gly476Ser and Thr499Ser. Moriyama et al. (2003) suggested that 1-Sst might be an exo-inulinase that possessed an additional fructosyltransferase activity in the presence of high concentrations of sucrose. Both proteins contain signal sequences at their $\mathrm{N}$-termini and are secreted as extracellular proteins. inuE was specifically induced on sucrose and inulin and repressed on fructose and glucose (Moriyama et al., 2003). In view of the $100 \%$ sequence identity of the A. niger CBS513.88 InuE and 1-Sst proteins, it is most likely that the $A$. niger InuE protein also has fructosyltransferase activity. However, further biochemical data about InuE are required. The InuE protein is also $91 \%$ identical to the Aspergillus awamori exo-inulinase Inu1 protein (Arand et al., 2002). A. awamori Inul is the only enzyme in this branch of the phylogenetic tree with levanase (hydrolysis of $\beta-2,6$ glycosidic linkages) activity. No transfructosylation activity has been reported for the $A$. awamori Inul protein. The different enzymic properties of the enzymes in this group are currently not well understood and need further biochemical investigation.

Two new invertase-like proteins (SucB and SucC) were identified in the genome of $A$. niger. As the two proteins contain all the conserved domains and the catalytic residues of GH32 family members it is very likely that these proteins contain sucrolytic or inulinolytic activities. Preliminary biochemical analysis of the recombinant SucB protein expressed in E. coli indeed indicates that SucB has hydrolysing activity on sucrose, 1-kestose and nystose as well as transfructosylation activity, resulting in the formation of 1-kestose and nystose from sucrose and 1-ketose, respectively (C. Goosen, unpublished results).

Both SucB and SucC are predicted to be intracellularly localized. The current gene models do not indicate the presence of typical hydrophobic signal sequences for targeting the protein into the endoplasmic reticulum in order to secrete the proteins via the secretory pathway. The algorithm (SecretomeP 1.0b prediction) used to predict the probability that SucB and SucC are exported via a nonclassical secretion pathway was not conclusive, as the prediction scores of the proteins were close to the threshold values. Moreover, these values should be interpreted with care, as the program has been trained using sequences of human non-classical exported proteins as no non-classical protein export has been shown to be present in filamentous fungi. Also in the genomes of other filamentous fungi GH32 family members without a predicted $\mathrm{N}$-terminal signal sequence were identified (Table 2), indicating that the presence of these intracellular enzymes is widespread among filamentous fungi and not specific to A. niger.

The presence of carbohydrate-degrading enzymes that do not contain a signal sequence is not limited to inulinolytic enzymes alone. In the genome of A. nidulans, 41 polysaccharide-degrading enzymes were predicted that lacked a signal sequence (de Vries et al., 2005). The presence of these intracellular enzymes strongly suggests that fungi are capable of transporting oligosaccharides into the cell which are subsequently hydrolysed by the intracellular enzymes. Alternatively, these intracellular enzymes may also possess transglycosylation activity, e.g. for the synthesis of inducer molecules that activate transcription factors.

The genome of $A$. niger also contained an ORF which showed homology to the group of exo-inulinases. However, to assemble this ORF encoding 137 amino acids, containing some of the conserved domains characteristic for family GH32 members, three putative frame shifts had to be corrected. Missing domains were not found in sequences adjacent to the predicted ORF. The genomic DNA region containing this putative inulinase (inuQ) was amplified by PCR from CBS513.88 and N402 and resequenced, which confirmed that the original DNA sequence was the correct one (data not shown). From this we concluded that inuQ is probably a pseudogene and not producing a functional protein. Northern analysis of mRNA isolated from cells grown on a variety of different carbon sources did not result in detection of inuQ mRNA, indicating that the gene is not transcribed under the conditions tested.

Expression analysis of the five genes revealed that the genes encoding the extracellular enzymes (SucA, InuE and InuA) are co-regulated and specifically expressed on sucrose and inulin. It is rather surprising that the inuA gene is induced by sucrose. Physiologically, there is no reason for the fungus to secrete this enzyme during growth with sucrose, since the enzyme does not hydrolyse the fructose-glucose disaccharide. However, a beneficial mechanism might have evolved, as sucrose and inulin might often be present together in plant material. Inulin is broken down primarily into fructose residues by the action of the exo-inulinase gene product and into inulo-oligosaccharides by the action of the endo-inulinase. The specific expression of sucA and inuE on inulin and sucrose is in agreement with previous 
observations (Wallis et al., 1997; Moriyama et al., 2003; Rehm et al., 1998). The expression of the single endoinulinase (inuA) gene in A. niger $\mathrm{N} 402$ on sucrose and inulin is different from that described for $i n u A$ (no expression observed) and inuB (constitutively expressed on inulin, fructose and glucose) in A. niger strain 12 (Akimoto et al., 1999). Analysis of the promoter sequences of the inuA genes of the A. niger CBS513.88 and N402 strains revealed that they contain five putative CreA-binding motifs (SYGGRG) in their first $1000 \mathrm{bp}$. creA encodes a wide-domain regulatory protein that binds to the promoter of target genes to prevent or decrease expression if a favourable carbon source (such as glucose or fructose) is present (Dowzer \& Kelly, 1991; Ruijter \& Visser, 1997). No such binding sites were observed when analysing the upstream sequence region of the $A$. niger 12 inu $B$ gene. This difference in the promoter sequences of inuA (A. niger CBS513.88 and $\mathrm{N} 402$ ) and of inuB (A. niger 12) may be responsible for their different expression patterns in relation to different carbon sources. Thus, A. niger strains CBS513.88, N402 and 12 differ both in the number of genes encoding endo-inulinases and in the way their expression is regulated.

Two lines of evidence led us to propose that sucrose, and not fructose, acts as an inducer for the expression of the genes encoding the inulinolytic enzymes. First, we showed that a low concentration of sucrose (50 $\mu \mathrm{M}$ initial concentration) induced the expression of the genes encoding the inulinolytic enzymes. The lower expression of the inulinolytic genes at higher sucrose concentrations suggested that sucrose (or the hydrolysis products of sucrose: glucose and fructose) caused carbon catabolite repression, possibly via the repressor protein CreA. The addition of $5 \mu \mathrm{M}$ sucrose resulted in relatively low levels of expression. Lowering the sucrose concentration even further did not result in detectable mRNA levels of any of the genes after $4 \mathrm{~h}$ of growth. At this point we can not rule out the possibility that also these lower concentrations of sucrose might have induced expression of the inulinolytic enzymes at earlier time points. Assuming that the mRNAs might not be very stable, we might have missed the induction as we have analysed the expression only after $4 \mathrm{~h}$. In an identical experimental set-up, also fructose was tested as an inducer, previously reported to act as an inducer for inulinase expression in the yeast K. lactis (Grootwassink \& Hewitt, 1983). We obtained no evidence that fructose acted as an inducer for the expression of the inulinolytic enzymes in $A$. niger. Formally, it is possible that the inulinolytic genes are induced by low influx levels of fructose which escaped detection after $4 \mathrm{~h}$ of growth. The addition of low concentrations of fructose may have resulted in starvation and the inability of the fungus to induce expression due to a lack of energy. One could postulate that fructose can act as an inducer at low concentrations but repress expression at higher concentrations. If this is the case, growth of the $\Delta$ creA strain on fructose should lead to a high level of expression of the genes encoding the inulinolytic enzymes. However, in Fig. 3(b), we show that the inulinolytic genes are not expressed in the $\Delta c r e A$ strain, giving additional support that fructose does not act as an inducer for the expression of the inulinolytic enzymes. The results obtained from our transcriptional study fit well with the early observations by Vainstein \& Peberdy (1991) that the invertase production in A. nidulans was the highest in sucrose medium and low in the culture fluid of fructose-grown mycelia. These findings indicate that the expression of inulinolytic enzymes is similarly regulated in A. nidulans and A. niger. As glucose, 1kestose or 1-nystose did not induce expression of the inulinolytic genes either, we suggest a mechanism by which sucrose is transported across the plasma membrane. Once intracellular, the sucrose molecule, or a derivative of it, acts as an inducer to activate a transcription factor to drive the expression of the inulinolytic genes. Current research is aimed at the identification of transcriptional activator(s) involved in the activation of expression of inulinolytic and/ or sucrolytic enzymes, and to determine the possible role of the intracellular $s u c B$ gene during growth on inulin and sucrose.

\section{ACKNOWLEDGEMENTS}

The authors thank Dr J. Visser for helpful discussions and Angelique Franken for technical assistance. We thank DSM for providing access to the A. niger genome sequence, Sensus and Cosun for providing inulin, and Avebe for providing starch. This research was supported by Senter IOP (Innovatief Onderzoeks Programma), The Netherlands (IGE01021).

\section{REFERENCES}

Akimoto, H., Kushima, T., Nakamura, T. \& Ohta, K. (1999). Transcriptional analysis of two endoinulinase genes inuA and inuB in Aspergillus niger and nucleotide sequences of their promoter regions. J Biosci Bioeng 88, 599-604.

Akimoto, H., Kiyota, N., Kushima, T., Nakamura, T. \& Ohta, K. (2000). Molecular cloning and sequence analysis of an endoinulinase gene from Penicillium sp. strain TN-88. Biosci Biotechnol Biochem 64, 2328-2335.

Alberto, F., Bignon, C., Sulzenbacher, G. \& Henrissat, B. (2004). The three-dimensional structure of invertase ( $\beta$-fructosidase) from Thermotoga maritima reveals a bimodular arrangement of an evolutionary relationship between retaining and inverting glycosidases. J Biol Chem 279, 18903-18910.

Arand, M., Golubev, A. M., Neto, J. R. B. \& 9 other authors (2002). Purification, characterization, gene cloning and preliminary X-ray data of the exo-inulinase from Aspergillus awamori. Biochem J 362, 131-135.

Bendtsen, J. D., Jensen, L. J., Blom, N., von Heijne, G. \& Brunak, S. (2004). Feature-based prediction of non-classical and leaderless protein secretion. Protein Eng Des Sel 17, 349-356.

Bennett, J. W. \& Lasure, L. L. (1991). Growth media. In More Gene Manipulations in Fungi, pp. 441-447. Edited by J. W. Bennet \& L. L. Lasure. San Diego: Academic Press.

Boddy, L. M., Berges, T., Barreau, C., Vainstein, C., Dobson, M. J., Balance, D. J. \& Peberdy, J. F. (1993). Purification and characterization of an Aspergillus niger invertase and its DNA sequence. Curr Genet 24, 60-66. 
Bos, C. J., Debets, A. J., Swart, K., Huybers, A., Kobus, G. \& Slakhorst, S. M. (1988). Genetic analysis and the construction of master strains for assignment of genes to six linkage groups in Aspergillus niger. Curr Genet 14, 437-443.

Cairns, A. J. (2003). Fructan biosynthesis in transgenic plants. J Exp Bot 54, 549-567.

Chávez, F. P., Pons, T., Delgado, J. M. \& Rodríguez, L. (1998). Cloning and sequence analysis of the gene encoding invertase (INV1) from the yeast Candida utilis. Yeast 14, 1223-1232.

Chenna, R., Sugawara, H., Koike, T., Lopez, R., Gibson, T. J., Higgins, D. G. \& Thompson, J. D. (2003). Multiple sequence alignment with the Clustal series of programs. Nucleic Acids Res 31, 3497-3500.

Chiou, C. Y., Wang, H. H. \& Shaw, G. C. (2002). Identification and characterization of the non-PTS fru locus of Bacillus megaterium ATCC 14581. Mol Genet Genomics 268, 240-248.

Coutinho, P. M. \& Henrissat, B. (1999). Carbohydrate-active enzymes: an integrated database approach. In Recent Advances in Carbohydrate Bioengineering, pp. 3-12. Edited by H. J. Gilbert, G. Davies, B. Henrissat \& B. Svensson. Cambridge: Royal Society of Chemistry.

de Ruiter-Jacobs, Y. M., Broekhuijsen, M., Unkles, S. E., Campbell, E. I., Kinghorn, J. R., Conteras, R., Pouwels, P. H. \& van den Hondel, C. A. M. J. J. (1989). A gene transfer system based on the homologous pyrG gene and efficient expression of bacterial genes in Aspergillus oryzae. Curr Genet 16, 159-163.

de Vries, R. P., van Grieken, C., van Kuyk, P. A. \& Wösten, H. A. B. (2005). The value of genome sequences in the rapid identification of novel genes encoding specific plant cell wall degrading enzymes. Curr Genom 6, 157-187.

Dowzer, C. E. \& Kelly, J. M. (1991). Analysis of the creA gene, a regulator of carbon catabolite repression in Aspergillus nidulans. Mol Cell Biol 11, 5701-5709.

Eddy, S. R. (1998). Profile hidden Markov models. Bioinformatics 14, 755-763.

Grootwassink, J. W. D. \& Hewitt, G. M. (1983). Inducible and constitutive formation of $\beta$-fructofuranosidase (inulase) in batch and continuous cultures of the yeast Kluyveromyces fragilis. J Gen Microbiol 129, 31-41.

Hendry, G. A. F. \& Wallace, R. K. (1993). The origin, distribution and evolutionary significance of fructans. In Science and Technology of Fructans, pp. 119-139. Edited by M. Suzuki \& N. J. Chatterton. Boca Raton, FL: CRC Press.

Heyer, A. G. \& Wendenburg, R. (2001). Gene cloning and functional characterization by heterologous expression of the fructosyltransferase of Aspergillus sydowi IAM 2544. Appl Environ Microbiol 67, 363-370.

Inoue, J. C., Nojima, H. \& Okayama, H. (1990). High efficiency transformation of Escherichia coli with plasmids. Gene 96, 23-28.

Kaplan, H. \& Hutkins, R. W. (2003). Metabolism of fructooligosacchrides by Lactobacillus paracasei 1195. Appl Environ Microbiol 69, 2217-2222.

Kim, H. Y. \& Choi, Y. J. (2001). Molecular characterization of cycloinulooligosaccharide fructanotransferase from Bacillus macerans. Appl Environ Microbiol 67, 995-1000.

Kulminskaya, A. A., Arand, M., Eneyskaya, E. V., Ivanen, D. R., Shabalin, K. A., Shishlyannikov, S. M., Saveliev, A. N., Korneeva, O. S. \& Neustroev, K. N. (2003). Biochemical characterization of Aspergillus awamori exoinulinase: substrate binding characteristics and regioselectivity of hydrolysis. Biochim Biophys Acta 1650, 22-29.

Laloux, O., Cassart, J. P., Delcour, J., Van Beeumen, J. \& Vandenhaute, J. (1991). Cloning and sequence analysis of the gene encoding invertase from the yeast Kluyveromyces marxianus var. marxianus ATCC 12424. FEBS Lett 289, 64-68.

L'Hocine, L., Wang, W., Jiang, B. \& Xu, S. (2000). Purification and partial characterization of fructosyltransferase and invertase from Aspergillus niger AS0023. J Biotechnol 81, 73-84.

Martin, I., Debarbouille, M., Ferrari, E., Klier, A. \& Rapoport, G. (1987). Characterization of the levanase gene of Bacillus subtilis which shows homology to yeast invertases. Mol Gen Genet 208, 177-184.

Meng, G. \& Futterer, K. (2003). Structural framework of fructosyl transfer in Bacillus subtilis levansucrase. Nat Struct Biol 10, 935-941.

Moriyama, S., Akimoto, H., Suetsugu, N., Kawasaki, S., Nakamura, T. \& Ohta, K. (2002). Purification and properties of an extracellular exoinulinase from Penicillium sp. strain TN-88 and sequence analysis of the encoding gene. Biosci Biotechnol Biochem 66, 1887-1896.

Moriyama, S., Tanaka, H., Uwataki, M., Muguruma, M. \& Ohta, K. (2003). Molecular cloning and characterization of an exoinulinase gene from Aspergillus niger strain 12 and its expression in Pichia pastoris. J Biosci Bioeng 96, 324-331.

Nagem, R. A., Rojas, A. L., Golubev, A. M., Korneeva, O. S., Eneyskaya, E. V., Kulminskaya, A. A., Neustroev, K. N. \& Polikarpov, I. (2004). Crystal structure of exo-inulinase from Aspergillus awamori: the enzyme fold and structural determinants of substrate recognition. J Mol Biol 344, 471-480.

Ohta, K., Akimoto, H., Matsuda, S., Toshimitsu, D. \& Nakamura, T. (1998). Molecular cloning and sequence analysis of two endoinulinase genes from Aspergillus niger. Biosci Biotechnol Biochem 62, 1731-1738.

Onodera, S., Murakami, T., Ito, H., Mori, H., Matsui, H., Honma, M., Chiba, S. \& Shiomi, N. (1996). Molecular cloning and nucleotide sequences of cDNA and gene encoding endo-inulinase from Penicillium purpurogenum. Biosci Biotechnol Biochem 60, 1780-1785.

Pandey, A., Soccol, C., Selvakumar, P., Socol, V. T., Krieger, N. \& Fontana, J. D. (1999). Recent developments in microbial inulinases. Its production, properties, and industrial applications. Appl Biochem Biotechnol 81, 35-52.

Penalva, M. A. \& Arst, H., Jr (2002). Regulation of gene expression by ambient $\mathrm{pH}$ in filamentous fungi and yeasts. Microbiol Mol Biol Rev 66, 426-446.

Pérez, J. A., Rodriguez, J., Rodriguez, L. \& Ruiz, T. (1996). Cloning and sequence analysis of the invertase gene INV1 from the yeast Pichia anomala. Curr Genet 29, 234-240.

Pilon-Smits, E. A. H., Ebskamp, M. J. M., Paul, M. J., Jeuken, M. J. W., Weisbeek, P. J. \& Smeekens, S. C. M. (1995). Evaluation of safety on inulin and oligofructose as dietary fiber. Plant Physiol 107, 125-130.

Pons, T., Olmea, O., Chinea, G., Beldarrain, A., Marquez, G., Acosta, N., Rodriguez, L. \& Valencia, A. (1998). Structure model for family 32 of glycosyl-hydrolase enzymes. Proteins 33, 383-395.

Pons, T., Naumoff, D. G., Martinez-Fleites, C. M. \& Hernández, L. (2004). Three acidic residues are at the active site of a beta-propeller architecture in glycoside hydrolase families 32, 43, 62 and 68 . Proteins 54, 424-432.

Punt, P. J. \& van den Hondel, C. A. M. J. J. (1992). Transformation of filamentous fungi based on hygromycin B and phleomycin resistance markers. Methods Enzymol 216, 447-457.

Punt, P. J., Oliver, R. P., Dingemanse, M. A., Pouwels, P. H. \& van den Hondel, C. A. M. J. J. (1987). Transformation of Aspergillus based on the hygromycin B resistance marker from Escherichia coli. Gene 56, 117-124.

Rehm, J., Wilimitzer, L. \& Heyer, L. G. (1998). Production of 1kestose in transgenic yeast expressing a fructosyl transferase from Aspergillus foetidus. J Bacteriol 180, 1305-1310.

Ritsema, T. \& Smeekens, S. (2003). Fructans: beneficial for plants and humans. Curr Opin Plant Biol 6, 223-230. 
Roberfroid, M. B. \& Delzenne, N. M. (1998). Dietary fructans. Annu Rev Nutr 18, 117-143.

Ruijter, G. J. \& Visser, J. (1997). Carbon repression in aspergilli. FEMS Microbiol Lett 151, 103-114.

Sangeetha, P. T., Ramesh, M. N. \& Prapulla, S. G. (2004). Production of fructosyl transferase by Aspergillus oryzae CFR 202 in solid-state fermentation using agricultural by-products. Appl Microbiol Biotechnol 65, 530-537.

Shroff, R. A., O'Connor, S. M., Hynes, M. J., Lockington, R. A. \& Kelly, J. M. (1997). Null alleles of creA, the regulator of carbon catabolite repression in Aspergillus nidulans. Fungal Genet Biol 22, 28-38.

Tanaka, N., Ohuchi, N., Mukai, Y. \& 7 other authors (1998). Isolation and characterization of an invertase and its repressor genes from Schizosaccharomyces pombe. Biochem Biophys Res Commun 245, 246-253.

Taussig, R. \& Carlson, M. (1983). Nucleotide sequences of the yeast SUC2 gene for invertase. Nucleic Acids Res 11, 1943-1954.

Thompson, J. D., Higgins, D. G. \& Gibson, T. J. (1994). CLUSTAL W: improving the sensitivity of progressive multiple sequence alignment through sequence weighting, position-specific gap penalties and weight matrix choice. Nucleic Acids Res 22, 4673-4680.
Uhm, T., Chae, S., Lee, D., Kim, S., Cassart, P. \& Vandenhaute, J. (1998). Cloning and nucleotide sequence of the endoinulinase-encoding gene, inu2, from Aspergillus ficuum. Biotechnol Lett 20, 809-812.

Vainstein, M. H. \& Peberdy, J. F. (1990). Solubilisation of a cell wall bound invertase in Aspergillus nidulans. FEMS Microbiol Lett 59, 265-269.

Vainstein, M. H. \& Peberdy, J. F. (1991). Regulation of invertase in Aspergillus nidulans: effect of different carbon sources. J Gen Microbiol 137, 315-321.

van Hartingsveldt, W., Mattern, I. E., van Zeijl, C. M., Pouwels, P. H. \& van den Hondel, C. A. (1987). Development of a homologous transformation system for Aspergillus niger based on the pyrG gene. Mol Gen Genet 206, 71-75.

Wallis, G. L. F., Hemming, F. W. \& Peberdy, J. F. (1997). Secretion of two $\beta$-fructofuranosidases by Aspergillus niger growing in sucrose. Arch Biochem Biophys 345, 214-222.

Yanai, K., Nakane, A., Kawate, A. \& Hirayama, M. (2001). Molecular cloning and characterization of the fructooligosaccharide-producing $\beta$-fructofuranosidase gene from Aspergillus niger ATCC20611. Biosci Biotechnol Biochem 65, 766-773.

Yun, J. W. (1996). Fructooligosaccharides: occurrence, preparation, and application. Enzyme Microb Technol 19, 107-117. 